\title{
Manifestation of a sellar hemangioblastoma due to pituitary apoplexy: a case report
}

Ralph T Schär ${ }^{1 *}$, Istvan Vajtai ${ }^{2}$, Rahel Sahli ${ }^{3}$ and Rolf W Seiler ${ }^{1}$

\begin{abstract}
Introduction: Hemangioblastomas are rare, benign tumors occurring in any part of the nervous system. Most are found as sporadic tumors in the cerebellum or spinal cord. However, these neoplasms are also associated with von Hippel-Lindau disease. We report a rare case of a sporadic sellar hemangioblastoma that became symptomatic due to pituitary apoplexy.
\end{abstract}

Case presentation: An 80-year-old, otherwise healthy Caucasian woman presented to our facility with severe headache attacks, hypocortisolism and blurred vision. A magnetic resonance imaging scan showed an acute hemorrhage of a known, stable and asymptomatic sellar mass lesion with chiasmatic compression accounting for our patient's acute visual impairment. The tumor was resected by a transnasal, transsphenoidal approach and histological examination revealed a capillary hemangioblastoma (World Health Organization grade I). Our patient recovered well and substitutional therapy was started for panhypopituitarism. A follow-up magnetic resonance imaging scan performed 16 months postoperatively showed good chiasmatic decompression with no tumor recurrence.

Conclusions: A review of the literature confirmed supratentorial locations of hemangioblastomas to be very unusual, especially within the sellar region. However, intrasellar hemangioblastoma must be considered in the differential diagnosis of pituitary apoplexy.

\section{Introduction}

Hemangioblastomas (HBLs) are benign, slowly growing and highly vascular tumors of the central nervous system (CNS), accounting for just $1 \%$ to $2.5 \%$ of all intracranial neoplasms, and $7 \%$ to $12 \%$ of primary tumors located in the posterior fossa [1]. In up to one in four cases of HBL there is an association with von HippelLindau (VHL) disease [2], a rare autosomal dominant condition that predisposes patients to multisystemic neoplastic disorders such as HBLs of the CNS, retinal angiomas, renal cell carcinoma, pheochromocytomas, serous cystadenomas and neuroendocrine tumors of the pancreas. VHL-associated HBLs tend to occur in younger patients and are often multiple in occurrence [2-4]. Sporadic HBLs, however, are mostly solitary lesions and predominantly found within the cerebellum or spinal cord. Supratentorial HBLs, which are more

\footnotetext{
* Correspondence: ralph.schaer@insel.ch

'Department of Neurosurgery, Inselspital, University Hospital Bern, 3010 Bern, Switzerland

Full list of author information is available at the end of the article
}

often associated with VHL disease [3,4], are a rare entity with just over 100 reported cases to date [5]. HBLs originating from the sellar or suprasellar region are exceptional, especially in cases with no association with VHL disease.

We report here what is, to the best of our knowledge, the seventh sporadic case in the literature of sellar HBL, which presented with pituitary apoplexy. We also review the literature on cases of HBL within the sellar and suprasellar region.

\section{Case presentation}

An 80-year-old Caucasian woman was admitted to our hospital with a 12-year history of an endocrine inactive steady sellar mass lesion (13 $\mathrm{mm}$ in diameter; Figure $1 \mathrm{~A}, \mathrm{~B})$. Our patient had been previously asymptomatic with no pituitary hormone deficiency or visual impairments. Moreover, our patient had a medical history of good health with only minor health issues that included hypertension and osteoporosis. However, prior to hospital admission, she had recently experienced two severe 

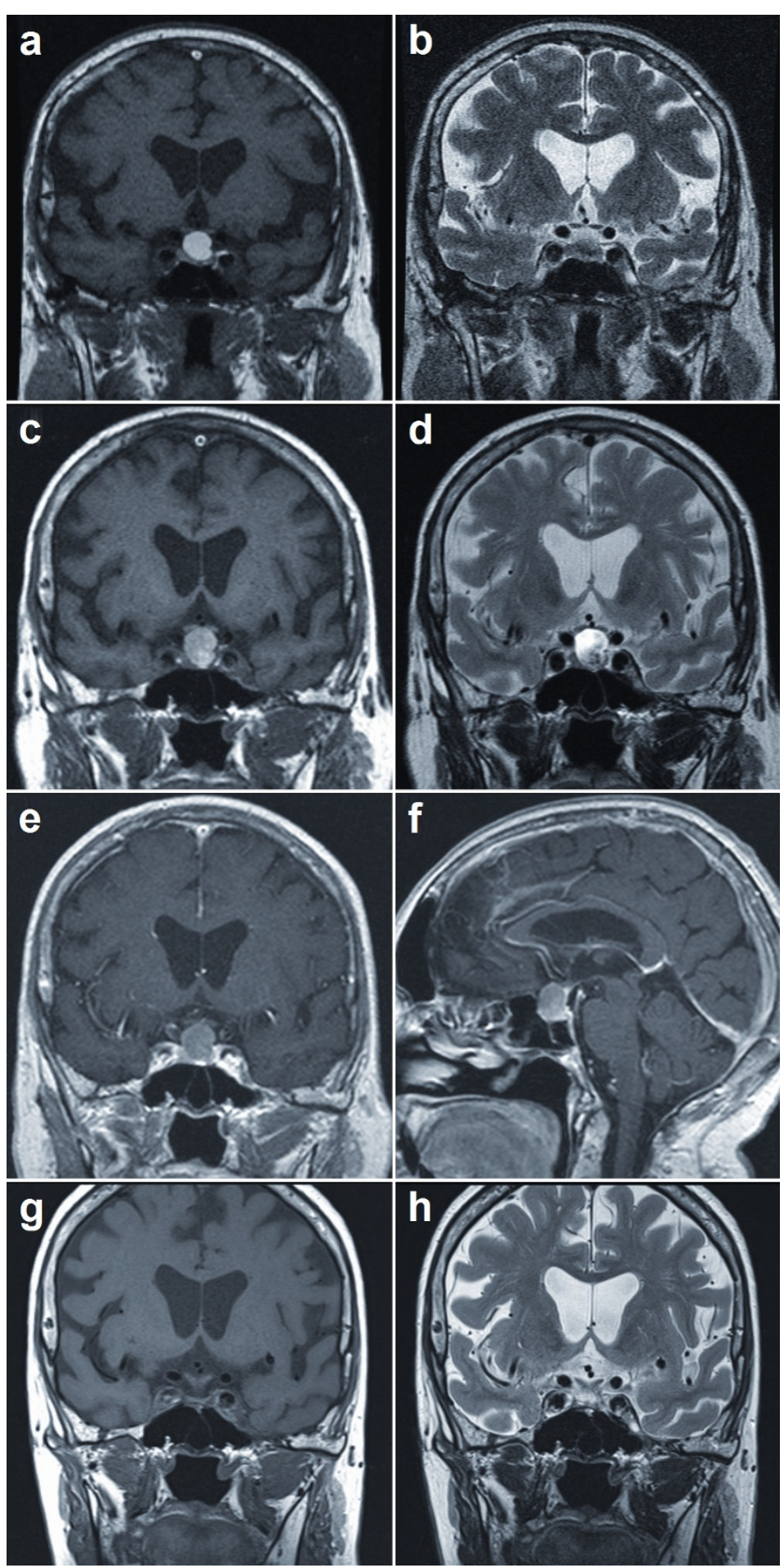

Figure 1 MRI images of patient's brain. (A, B) T1- and T2- weighted MRI scans taken two years prior to current presentation. (C) T1-weighted MRI scan of patient's brain, revealing a partly vesicular hyperintense, and slightly increased (compared to A and B) intrasellar and suprasellar mass of $16 \mathrm{~mm}$ in diameter, with progressive compression of the prechiasmatic portions of her optic nerves bilaterally. (D) T2-weighted MRI scan showing the vesicular portion as hypointense; normal pituitary tissue could not be clearly delineated. (E, F) There was no evident enhancement on T1-weighted imaging after intravenous administration of gadolinium. (G, H) An MRI scan taken 16 months postoperatively showed regular display of the remaining pituitary gland with good chiasmatic decompression and no signs of tumor recurrence. 
headache attacks; the last episode was accompanied by nausea, vomiting and blurred vision. Hyponatremia (120 $\mathrm{mEq} / \mathrm{L})$ with low serum osmolality $(247 \mathrm{mOsm} / \mathrm{L})$ and highly elevated urine osmolality $(695 \mathrm{mOsm} / \mathrm{L})$ were detected. An endocrinological investigation revealed hypocortisolism with no other hormone disturbances. Fundoscopy showed no pathological findings. However, further ophthalmologic examination with Goldman perimetry confirmed a bitemporal hemianopsia accentuated on her right side. Her neurological examination results were otherwise normal. After substitution therapy with hydrocortisone, our patient rapidly improved and her headaches subsided.

Findings from a magnetic resonance imaging (MRI) scan were suggestive of an acute hemorrhage of the sellar process, consistent with pituitary apoplexy (Figure $1 \mathrm{C}-\mathrm{F})$. Except for an age-consistent vascular leukoencephalopathy, the diagnostic imaging showed no further pathological findings. Our tentative diagnosis at this point was a pituitary adenoma with pituitary apoplexy.

Due to these clinical and radiological findings, the decision was made to surgically remove the tumor. A gross total extirpation using a transnasal, transsphenoidal approach to the pituitary mass was successfully performed. Intraoperatively, the tumor appeared yellowishbrown, was relatively firm and was located within a sellar hematoma cavity, which was evacuated.

Postoperatively, our patient's visual field deficits improved markedly on clinical examination and Goldman perimetry confirmed a partial recovery of her bitemporal visual field deficits. Endocrinological studies showed panhypopituitarism with partial and transient diabetes insipidus. Our patient received substitution therapy with hydrocortisone, levothyroxine and transient therapy with desmopressin. Overall, our patient remained in good health with a satisfactory level of performance. A repeat MRI scan taken 16 months after surgery showed good chiasmatic decompression with no residual tumor mass (Figure 1G, $\mathrm{H}$ ).

The resected tumor was examined with light microscopy, which revealed a small, well circumscribed, nonadenomatous tumor surrounded by slightly compressed remnants of adenohypophyseal parenchyma (Figure 2AC). The tumor was richly vascularized with an observable reticular mesh of thin-walled capillaries interspersed with large epithelioid-looking cells (Figure 2D, E). Pale eosinophilic cytoplasm showed xanthomatous or vacuolar change (Figure 2F). Immunohistochemistry confirmed the expression of the endothelial-associated markers CD31 and CD34 in the intratumoral capillaries, although not in the stromal cells themselves. Conversely, the stromal cells were diffusely immunoreactive for vimentin, with a minority of cells also coexpressing S100 protein and epithelial membrane antigen (Figure
2G). No inflammatory infiltrate was detected except for the occasional mast cell (Figure 2H). Staining for cytokeratins tested negative, as did the Langerhans-cell-associated marker CD1a. Less than 1\% of lesional cell nuclei were labeled with the cell proliferation-associated antigen Ki-67.

Given the above findings, we identified the tumor as an intrapituitary example of capillary hemangioblastoma (World Health Organization grade I). Since our patient displayed no clinical stigmata of VHL disease, genetic testing was not performed.

\section{Discussion}

Based on previous studies, the occurrence of supratentorial HBLs is thought to be in the range of $2 \%$ to $8 \%$ of all HBLs [3,4,6], accounting for 116 reported cases from 1902 to 2004 [5]. Supratentorial tumors were mostly found in the frontal, parietal or temporal lobes [7].

No more than 27 reported cases to date (including our patient's case) describe HBLs originating in the sellar and suprasellar region (see [1] and references therein, and $[2,8-11])$ of which 18 were confirmed with histopathology (Table 1). Of the 27 cases, only seven (26\%) were sporadic. In accordance with previous studies, the average age at presentation of patients with sporadic HBLs (52.4 years) was greater than patients affected with the VHL syndrome (35.8 years), excluding two cases with postmortem diagnosis (Table 1, cases 1 and 2 ) and one case not stating VHL association [10].

While information on clinical features is derived from reports of sellar and suprasellar HBLs causing symptoms generally related to mass effect, a long presymptomatic stage can be assumed. Of a total of 250 patients with VHL disease enrolled in a prospective study, eight incidentally discovered HBLs located in the pituitary stalk remained stable during a mean follow-up of $41.4 \pm 14$ months [8] Also, in our patient's case, the sellar lesion, initially diagnosed as an incidental finding on MRI performed for an unrelated reason, remained stable for 12 years.

Overall, the unexpected nature and the unspecific presentation render an accurate preoperative diagnosis of sporadic HBLs challenging. In our patient, the apoplexy of a well known sellar mass suggested a pituitary macroadenoma; clinical apoplexy was observed in $0.6 \%$ to $9.0 \%$ of these cases [12]. The typical, albeit not pathognomonic, radiological feature of HBLs is that they can be identified as an enhancing lesion on T1-weighted MRI scans. This finding was lacking in our case due to acute hemorrhage of the lesion.

The main histological differential diagnosis of HBL, irrespective of location, is metastatic clear cell carcinoma. In our patient, lack of immunoreactivity for cytokeratins along with a negligibly low proliferation index allowed for this alternative to be confidently ruled out. 


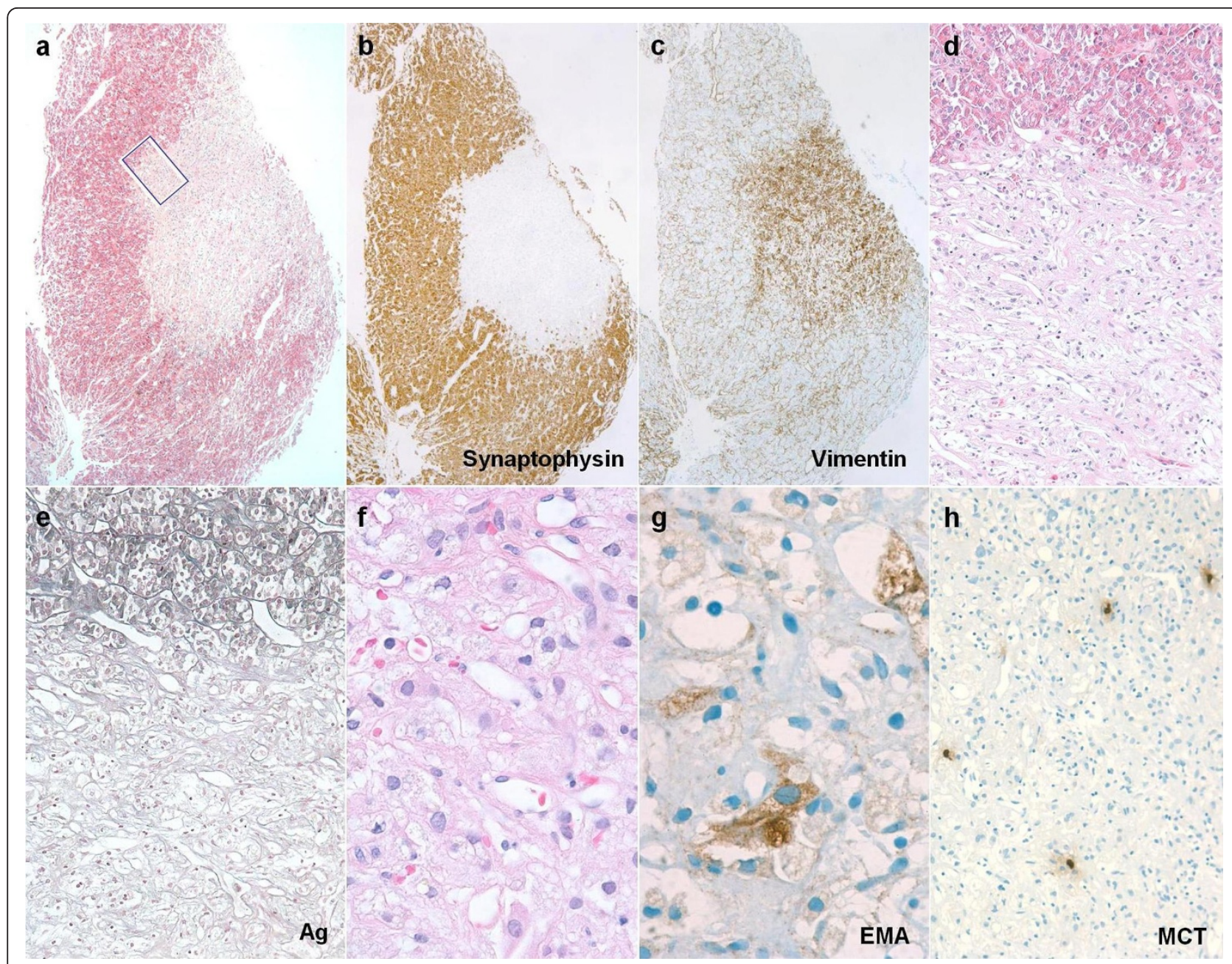

Figure 2 Overview showing well circumscribed HBL nodule partly surrounded by a crescent-shaped mantle of peritumoral pituitary parenchyma. (A) Optical contrast between the faint eosinophilic hue of the HBL nidus and bright red granular quality of adjacent somatotrophs. (B, C) Adjacent section planes treated with immunohistochemistry, showing segregation of adenohypophyseal neuroendocrine cells (B) and mesenchymal-like immunophenotype (C) of the HBL nodule. (D) Detail view of boxed area in (A) shows the HBL to be comprised of an irregular reticular meshwork of tortuous, thin-walled capillaries that tend to be interspersed with pale stromal cells. (E) Gomori's reticulin stain highlighting the brisk transition from the acinar outline of native adenohypophyseal follicles (upper third) to the vascular-dominated basement membrane pattern of HBL. (F) High-power view of HBL showing polygonal contours and cytoplasmic vacuolation of stromal cells encased by capillaries. Some nuclear pleomorphism, as also evident in this microscopic field, is of no prognostic significance. (G) A minority of stromal cells were stained for epithelial membrane antigen. $(\mathrm{H})$ Scattered mast cells are a characteristic complement of HBL. If not labeled otherwise, microphotographs have been made using hematoxylin and eosin stain. Original magnifications: $(A-C) \times 30 ;(D, E, H) \times 100 ;(F, G) \times$ 400 .

In the peculiar context of intrapituitary occurrence, we also addressed the possibility of xanthomatous hypophysitis and Langerhans cell histiocytosis [13,14]. The noninflammatory character of the lesion in our case strongly argued against xanthomatous hypophysitis (or sellar xanthogranuloma). However, the circumscribed rather than infiltrative pattern of this solitary intrapituitary nodule, one devoid of CD1a immunoreactivity, was an intuitive obstacle against seriously considering Langerhans cell histiocytosis.

\section{Conclusions}

Supratentorial HBLs are rare, especially within the sellar region and without an association with VHL disease. However, our patient's case shows that intrasellar HBL must be considered in the differential diagnosis of pituitary apoplexy.

\section{Consent}

Written informed consent was obtained from the patient for publication of this case report and any accompanying 
Table 1 Literature review of reported cases of HBL confirmed by histopathology in the sellar region

\begin{tabular}{|c|c|c|c|c|c|c|c|}
\hline Case & Reference & $\begin{array}{l}\text { Age } \\
\text { (years), } \\
\text { sex }\end{array}$ & Symptoms & Location & VHL & $\begin{array}{l}\text { Surgery for } \\
\text { sellar HBL }\end{array}$ & Follow-up \\
\hline 1 & {$[15]$} & $84, M$ & None & $\begin{array}{l}\text { Intrasellar } \\
\text { (anterior } \\
\text { lobe) }\end{array}$ & Yes & $\begin{array}{l}\text { None, autoptic } \\
\text { finding }\end{array}$ & NA \\
\hline 2 & {$[16]$} & $26, M$ & Blurred vision, headache, ataxia & $\begin{array}{l}\text { Intrasellar } \\
\text { (anterior } \\
\text { lobe) }\end{array}$ & Yes & $\begin{array}{l}\text { None, autoptic } \\
\text { finding }\end{array}$ & NA \\
\hline 3 & {$[17]$} & $19, \mathrm{M}$ & Nausea, vertigo, ataxia & Suprasellar & Yes & Total resection & NA \\
\hline 4 & [18] & $19, F$ & Headache, amenorrhea-galactorrhea & $\begin{array}{l}\text { Pituitary } \\
\text { stalk }\end{array}$ & No & Total resection & Panhypopituitarism \\
\hline 5 & {$[2]$} & $35, F$ & $\begin{array}{l}\text { Headache, amenorrhea, diabetes } \\
\text { insipidus }\end{array}$ & $\begin{array}{l}\text { Pituitary } \\
\text { stalk }\end{array}$ & No & Yes, details NA & NA \\
\hline 6 & {$[9]$} & $60, F$ & Partial hemianopsia & Suprasellar & Yes & $\begin{array}{l}\text { None, gamma } \\
\text { knife radiosurgery }\end{array}$ & $\begin{array}{l}\text { Syndrome of inappropriate secretion of } \\
\text { antidiuretic hormone at } 22 \text {-month follow- } \\
\text { up }\end{array}$ \\
\hline 7 & [19] & $11, F$ & $\begin{array}{l}\text { Headache, bitemporal hemianopsia, } \\
\text { adrenocorticotropic hormone and } \\
\text { growth hormone deficiency }\end{array}$ & Intrasellar & Yes & $\begin{array}{l}\text { Subtotal resection } \\
\text { and adjuvant } \\
\text { radiosurgery }\end{array}$ & $\begin{array}{l}\text { Headache improved, no residual tumor, } \\
\text { panhypopituitarism }\end{array}$ \\
\hline 8 & {$[20]$} & $57, \mathrm{~F}$ & Diplopia, sixth nerve palsy & $\begin{array}{l}\text { Intrasellar } \\
\text { and } \\
\text { sphenoid } \\
\text { sinus }\end{array}$ & No & Subtotal resection & Partial improvement of sixth nerve palsy \\
\hline 9 & {$[21]$} & $20, F$ & $\begin{array}{l}\text { Panhypopituitarism, diabetes } \\
\text { insipidus }\end{array}$ & $\begin{array}{l}\text { Suprasellar } \\
\text { and } \\
\text { pituitary } \\
\text { stalk }\end{array}$ & Yes & Total resection & $\begin{array}{l}\text { Stable panhypopituitarism, no residual } \\
\text { tumor at } 53 \text {-month follow-up }\end{array}$ \\
\hline 10 & {$[22]$} & $33, F$ & Irregular menses & $\begin{array}{l}\text { Pituitary } \\
\text { stalk }\end{array}$ & Yes & Subtotal resection & $\begin{array}{l}\text { No neurological deficits or pituitary } \\
\text { dysfunction, stable residual tumor at six- } \\
\text { month follow-up }\end{array}$ \\
\hline 11 & {$[23]$} & $62, \mathrm{M}$ & Visual disturbance & Suprasellar & No & Total resection & NA \\
\hline 12 & {$[24]$} & $60, M$ & $\begin{array}{l}\text { Bitemporal hemianopsia, } \\
\text { panhypopituitarism }\end{array}$ & $\begin{array}{l}\text { Intrasellar } \\
\text { and } \\
\text { suprasellar }\end{array}$ & No & $\begin{array}{l}\text { Transsphenoidal } \\
\text { biopsy }\end{array}$ & NA \\
\hline$\overline{13}$ & {$[25]$} & $40, F$ & $\begin{array}{l}\text { Oligomenorrhea, cognitive } \\
\text { impairment }\end{array}$ & $\begin{array}{l}\text { Intrasellar } \\
\text { and } \\
\text { suprasellar }\end{array}$ & Yes & $\begin{array}{l}\text { Subtotal resection } \\
\text { and gamma knife } \\
\text { radiosurgery }\end{array}$ & NA \\
\hline 14 & {$[26]$} & $54, \mathrm{M}$ & Headache, visual loss & Suprasellar & No & Total resection & $\begin{array}{l}\text { Partial improvement of visual loss, no } \\
\text { tumor recurrence at five-year follow-up }\end{array}$ \\
\hline 15 & {$[26]$} & $38, \mathrm{M}$ & Headache, visual loss & Suprasellar & Yes & Subtotal resection & NA \\
\hline 16 & {$[1]$} & $51, F$ & Blurred vision & $\begin{array}{l}\text { Pituitary } \\
\text { stalk }\end{array}$ & Yes & Total resection & $\begin{array}{l}\text { Panhypopituitarism, visual acuity } \\
\text { improved }\end{array}$ \\
\hline 17 & {$[27]$} & $59, F$ & Fatigue, visual loss & Suprasellar & NS & Total resection & $\begin{array}{l}\text { Panhypopituitarism, no tumor recurrence } \\
\text { at three-year follow-up }\end{array}$ \\
\hline 18 & $\begin{array}{l}\text { Present } \\
\text { case }\end{array}$ & $80, F$ & $\begin{array}{l}\text { Headache, bitemporal hemianopsia, } \\
\text { hypocortisolism }\end{array}$ & Intrasellar & No & Total resection & $\begin{array}{l}\text { Headache subsided, visual field deficits } \\
\text { improved, panhypopituitarism, no tumor } \\
\text { recurrence at 16-month follow-up }\end{array}$ \\
\hline
\end{tabular}

F: female patient; M: male patient; NA: not available.

images. A copy of the written consent is available for review by the Editor-in-Chief of this journal.

\section{Acknowledgements}

We would like to thank our patient for kindly allowing publication of this case. There was no funding for this study. The authors thank Susan Wieting, Bern University Hospital, Department of Neurosurgery, Publications Office, Bern Switzerland for proofreading the final manuscript.

\section{Author details}

'Department of Neurosurgery, Inselspital, University Hospital Bern, 3010 Bern, Switzerland. ${ }^{2}$ Section of Neuropathology, Institute of Pathology, University of Bern, 3010 Bern, Switzerland. ${ }^{3}$ Division of Endocrinology, Diabetes and Clinical Nutrition, Inselspital, University Hospital Bern, 3010 Bern, Switzerland.

\section{Authors' contributions}

RTS was responsible for the conception and drafting of the manuscript, and analyzed and reviewed the literature relevant to this case report. IV performed the histological examination and was a major contributor to 
writing the manuscript. RS was largely involved in patient management and also contributed to writing the article. RWS performed the operative resection of the tumor and critically revised the article. All authors read and approved the final manuscript.

\section{Competing interests}

The authors declare that they have no competing interests.

Received: 28 April 2011 Accepted: 4 October 2011

Published: 4 October 2011

\section{References}

1. Fomekong E, Hernalsteen D, Godfraind C, D'Haens J, Raftopoulos C: Pituitary stalk hemangioblastoma: the fourth case report and review of the literature. Clin Neurol Neurosurg 2007, 109:292-298.

2. Neumann HP, Eggert HR, Weigel K, Friedburg H, Wiestler OD, Schollmeyer P: Hemangioblastomas of the central nervous system. A 10year study with special reference to von Hippel-Lindau syndrome. $J$ Neurosurg 1989, 70:24-30

3. Conway JE, Chou D, Clatterbuck RE, Brem H, Long DM, Rigamonti D: Hemangioblastomas of the central nervous system in von Hippel-Lindau syndrome and sporadic disease. Neurosurgery 2001, 48:55-63.

4. Wanebo JE, Lonser RR, Glenn GM, Oldfield EH: The natural history of hemangioblastomas of the central nervous system in patients with von Hippel-Lindau disease. J Neurosurg 2003, 98:82-94.

5. Sherman JH, Le BH, Okonkwo DO, Jane JA: Supratentorial dural-based hemangioblastoma not associated with von Hippel Lindau complex. Acta Neurochir 2007, 149:969-972.

6. Sharma RR, Cast IP, O'Brien C: Supratentorial haemangioblastoma not associated with Von Hippel Lindau complex or polycythaemia: case report and literature review. Br J Neurosurg 1995, 9:81-84.

7. Iplikçioglu AC, Yaradanakul V, Trakya U: Supratentorial haemangioblastoma: appearances on MR imaging. Br I Neurosurg 1997, 11:576-578.

8. Lonser RR, Butman JA, Kiringoda R, Song D, Oldfield EH: Pituitary stalk hemangioblastomas in von Hippel-Lindau disease. J Neurosurg 2009, 110:350-353.

9. Niemelä M, Lim YJ, Söderman M, Jääskeläinen J, Lindquist C: Gamma knife radiosurgery in 11 hemangioblastomas. J Neurosurg 1996, 85:591-596.

10. Miyata S, Mikami T, Minamida Y, Akiyama Y, Houkin K: Suprasellar hemangioblastoma. J Neuroophthalmol 2008, 28:325-326.

11. Sajadi A, de Tribolet N: Unusual locations of hemangioblastomas. Case illustration. J Neurosurg 2002, 97:727.

12. Semple PL, Webb MK, de Villiers JC, Laws ER Jr: Pituitary apoplexy. Neurosurgery 2005, 56:65-72.

13. Burt MG, Morey AL, Turner JJ, Pell M, Sheehy JP, Ho KK: Xanthomatous pituitary lesions: a report of two cases and review of the literature. Pituitary 2003, 6:161-168.

14. Modan-Moses D, Weintraub M, Meyerovitch J, Segal-Lieberman G, Bielora B: Hypopituitarism in langerhans cell histiocytosis: seven cases and literature review. J Endocrinol Invest 2001, 24:612-617.

15. Rho YM: Von Hippel-Lindau's disease: a report of five cases. Can Med Assoc J 1969, 101:135-142.

16. Dan NG, Smith DE: Pituitary hemangioblastoma in a patient with von Hippel-Lindau disease. Case report. J Neurosurg 1975, 42:232-235.

17. O'Reilly GV, Rumbaugh CL, Bowens M, Kido DK, Naheedy MH: Supratentorial haemangioblastoma: the diagnostic roles of computed tomography and angiography. Clin Radiol 1981, 32:389-392.

18. Grisoli F, Gambarelli D, Raybaud C, Guibout M, Leclercq T: Suprasellar hemangioblastoma. Surg Neurol 1984, 22:257-262.

19. Sawin PD, Follett KA, Wen BC, Laws ER Jr: Symptomatic intrasellar hemangioblastoma in a child treated with subtotal resection and adjuvant radiosurgery. Case report. J Neurosurg 1996, 84:1046-1050.

20. Kachhara R, Nair S, Radhakrishnan W: Sellar-sphenoid sinus hemangioblastoma: case report. Surg Neurol 1998, 50:461-463.

21. Kouri JG, Chen MY, Watson JC, Oldfield EH: Resection of suprasellar tumors by using a modified transsphenoidal approach. Report of four cases. J Neurosurg 2000, 92:1028-1035.

22. Goto T, Nishi T, Kunitoku N, Yamamoto K, Kitamura I, Takeshima H, Kochi M, Nakazato Y, Kuratsu J, Ushio Y: Suprasellar hemangioblastoma in a patient with von Hippel-Lindau disease confirmed by germline mutation study: case report and review of the literature. Surg Neurol 2001, 56:22-26.

23. Ikeda M, Asada M, Yamashita H, Ishikawa A, Tamaki N: A case of suprasellar hemangioblastoma with thoracic meningioma. No Shinkei Geka 2001, 29:679-683.

24. Rumboldt Z, Gnjidic Z, Talan-Hranilovic J, Vrkljan M: Intrasellar hemangioblastoma: characteristic prominent vessels on MR imaging. AJR Am J Roentgenol 2003, 180:1480-1481.

25. Wasenko JJ, Rodziewicz GS: Suprasellar hemangioblastoma in Von HippelLindau disease: a case report. Clin Imaging 2003, 27:18-22.

26. Peker S, Kurtkaya-Yapicier O, Sun I, Sav A, Pamir MN: Suprasellar haemangioblastoma. Report of two cases and review of the literature. $J$ Clin Neurosci 2005, 12:85-89.

27. Miyata S, Mikami T, Minamida Y, Akiyama Y, Houkin K: Suprasellar hemangioblastoma. J Neuroophthalmol 2008, 28:325-326.

doi:10.1186/1752-1947-5-496

Cite this article as: Schär et al:: Manifestation of a sellar

hemangioblastoma due to pituitary apoplexy: a case report. Journal of Medical Case Reports 2011 5:496.

\section{Submit your next manuscript to BioMed Central and take full advantage of:}

- Convenient online submission

- Thorough peer review

- No space constraints or color figure charges

- Immediate publication on acceptance

- Inclusion in PubMed, CAS, Scopus and Google Scholar

- Research which is freely available for redistribution

Submit your manuscript at www.biomedcentral.com/submit
Ciomed Central 